9.Malynovska O. Migracija i koronakryza. Migracia. 2020. №6 (220). P.12. [in Ukrainian].

10. Novosad K.J. Socialni ryzyky mignarodnoi trudovoi migracii z Ukrainy. Diss. dokt. soc. nauk. Ujgorod. 2018. 275 p. [in Ukrainian].

11. Pak N. Nekontroljovana migracija jak zagroza bezpeci krajin Jevropejskogo Sojuzu. Visnyk KNU imeni Tarasa Shevchenka. 2016. №44-45. P. 30-32. [in Ukrainian].

12. Homjak A. Integracija migrantiv u jevropeiski suspilstva: integracijna polityka ta gromadska dymka. Visnyk NTUU "KPI". Politologiva. Sociologiya. Pravo. 2019. №3(43). P.139-146. [in Ukrainian].

13. Algash V., Pittel A. Suchasna migracijna kryza jak vyklyk dlja EU. Pidpryjemnyctvo, gospodarstvo i pravo. 2019 . №12. P.334-338. [in Ukrainian].

14. Mamonova V.A. Multykulturalizm: raznoobrazie I mnogestvo. Intelros. 2007. № 2. P. 29-38. [in Russian].

15. Treschaninh D. Multykulturalizm - eto tupikovaja strategija. Evropa peresmatrivaet otnoshenija s nacmenshynstvami, Rosia ostaetsa verna vybranomu puti. 2011. Available at: https://svpressa.ru/society/article/38872/.[in Russian].

16. Asymiliacia. Politychna encyclopedia/ red.kol.: J. Levenec, J. Shapoval. K. : Parlamentske vydavnyctvo, 2011. P. $42-43$. Available at: https://archive.org/details/Politychna/page/n41/mode/2up. [in Ukrainian].

17. Rudik O. Evropejizacia jak process ta predmet doslidgen. Evropejizacia publichnogo admistruvannja v Ukraini v konteksti evropejskoi integracii: materialy nauk.-prakt. Konferemcii. 17 .12. 2009, Dnipropetrovsk / za zag. red. L.L. Prokopenko. D.: DRIDU NADU, 2009. 224 p. [in Ukrainian].

18. Getmanchuk A. Vitrynna evropejizacia. Mignarodnyi centr perspectyvnyh doslidgen. Evropejski akcenty. 2009. № 1. 4 of september.

19. Mihel D. Vyznachennia poniattia procesu “evropejizacia” ta jogo vplyv na suchasne suspilstvo. Naukovi praci. Politologia. Vol. 150. P. 162. 2011. Available at: http://politics.chdu.edu.ua/article/download/75273/70785/0. [in Ukrainian].

20. Bureiko N. Evrointegracia vs evropejizacia . Kalka tez do samitu Ukraina-EU. "Ukrainska pryzma". Mignarodna bezpeka ta Evrointegracia Ukrainy. Evropeiska Pravda. Available at: 2016. https://www.eurointegration.com.ua/experts/2016/11/24/7057925/.[in Ukrainian].

21. Resolution adopted by the General Assembly on 19 December 2018 [without reference to a Main Committee (A/73/L.66)] 73/195. Global Compact for Safe, Orderly and Regular Migration/General Assembly United Nations. URL: https://migrationnetwork.un.org/sites/default/files/docs/gcm-n1845199.pdf. [in English].

22. Vainman T. Dozvil na robotu: scho vazlyvo znaty pro nimecky "blakytnu kartu". Deutsche Welle. 2019. Available at: $\quad$ https:// www.dw.com/uk/дозвіл-на-роботу-що-важливо-знати-про-німецьку-блакитну-карту/a-48024720. [in Ukrainian].

Дата подання публікації 16.09.2021 p.

УДК 330.4:339.9(477)

Савош Л.В., к.е.н., доцент, Larysa Savosh, Candidate of Economic Sciences, Associate Professor https://orcid.org/0000-0003-0831-201X

Павлюк Л.В., к.е.н, доцент, Liudmyla Pavliuk, Candidate of Economic Sciences, Associate Professor https://orcid.org/0000-0003-2519-3243

Кравчук П.Я., к.е.н, доцент,

Pavlo Kravchuk, Candidate of Economic Sciences, Associate Professor https://orcid.org/0000-0002-4736-4915

\title{
ЕКОНОМІКО-МАТЕМАТИЧНЕ МОДЕЛЮВАННЯ ЗАЛЕЖНОСТІ СОЦІАЛЬНО-ЕКОНОМІЧНОЇ СФЕРИ УКРАЇНИ ВІД ЗОВНІШНЬО-ЕКОНОМІЧНИХ ЧИНИКІВ
}

\author{
Луцький національний технічний університет
}

У статті проведено дослідження залежності рівня розвитку соціально-економічної сфери України від зовнішньо-економічних чинників. Затвердженим на законодавчому рівні вектором розвитку України є інтеграція до європейського та світового господарства. Наша країна має значні конкурентні переваги, такі як: зручне географічне розташування, високий рівень забезпечення природними ресурсами, доступність трудових ресурсів тощо. Зважаючи на історичні особливості розвитку вітчизняної економіки, зокрема, та й України загалом, процеси інтеграції чинять не лише позитивний вплив на вітчизняну економіку та рівень добробуту населення, але й несуть суттєві виклики та загрози. Саме у цьому полягає актуальність обраної теми досліджень наукової публікації.

Основним показником, що характеризує рівень розвитку соціально-економічної сфери країни $є$ значення валового внутрішнього продукту. Основними чинниками зовнішньо-економічної діяльності $\epsilon$ експорт та імпорт товарів та послуг, зовнішньо-торговельне сальдо та прямі іноземні інвестиції. Для 
проведення дослідження обрано часовий період з 2001 року до 2020 року. Висунуте припущення про високу залежність між ВВП та експортом товарів та послуг не підтвердилося в процесі досліджень. В результаті проведених досліджень з використанням економіко-математичного моделювання підтверджено високу залежність ВВП України від імпорту товарів та послуг.

Такі результати дослідження пояснюються структурою вітчизняного імпорту, у якому переважають продукція машинобудування, хімічної промисловості та мінеральна продукція. Це формує високу залежність вітчизняної промисловості, і соціально-економічної сфери загалом, від імпортованої продукції, що є одним із основних негативних наслідків економічної інтеграції. Для зменшення ризиків економічних інтеграційних процесів необхідно впровадження ресурсо- та енергозберігаючих технологій у промисловості, що дозволить підвищити конкурентоспроможність вітчизняної продукції, активізація інноваційних процесів у національному господарстві, активізація експорту та підтримка вітчизняного товаровиробника.

Ключові слова: економіко-математичне моделювання, сочіально-економічна сфера, ВВП, зовнішньо-економічні чинники, експорт товарів та послуг, імпорт товарів та послуг.

\title{
ECONOMIC AND MATHEMATICAL MODELING OF THE DEPENDENCE OF THE SOCIO-ECONOMIC SPHERE OF UKRAINE FROM EXTERNAL-ECONOMIC FACTORS
}

\author{
Lutsk National Technical University
}

The article examines the dependence of the level of development of the socio-economic sphere of Ukraine on foreign economic factors. The vector of Ukraine's development approved at the legislative level is integration into the European and world economy. Our country has significant competitive advantages, such as convenient geographical location, high level of natural resources, availability of labor resources, and so on. Given the historical features of the domestic economy, in particular, and Ukraine as a whole, integration processes not only have a positive impact on the domestic economy and the welfare of the population but also pose significant challenges and threats. This is the relevance of the chosen research topic of a scientific publication.

The main indicator that characterizes the level of development of the socio-economic sphere of the country is the value of the gross domestic product. The main factors of foreign economic activity are exports and imports of goods and services, foreign trade balance, and foreign direct investment. The period from 2001 to 2020 was chosen for the study. The assumption of a high relationship between GDP and exports of goods and services was not confirmed in the study. As a result of research using economic and mathematical modeling, the high dependence of Ukraine's GDP on imports of goods and services has been confirmed.

These results of the study are explained by the structure of domestic imports, which is dominated by products of mechanical engineering, chemical industry, and mineral products. This creates a high dependence of domestic industry and socio-economic sphere in general on imported products, which is one of the main negative consequences of economic integration. To reduce the risks of economic integration processes, it is necessary to introduce resource- and energy-saving technologies in the industry, which will increase the competitiveness of domestic products. It is important to intensify innovation processes in the national economy, increase exports and support domestic producers.

Key words: economic and mathematical modeling, socio-economic sphere, GDP, external-economic factors, exports of goods and services, imports of goods and services.

Постановка проблеми у загальному вигляді i ïi зв'язок 3 важливими науковими та практичними завданнями. Серед основних засад здійснення зовнішньої політики України ключове місце займає інтеграція країни у європейський та світовий економічний простір [1]. Разом з тим, стрімка активізація інтеграційних процесів має як позитивні, так і негативні наслідки для соціально-економічного розвитку країни та добробуту іï населення [2, с. 97]. До основних ризиків інтеграції слід віднести диспропорції у розвитку національної економіки у бік експорто-орієнтованих галузей, зростання економічної залежності держави, ослаблення конкурентних переваг національних виробників на внутрішньому ринку, збільшення зовнішньої заборгованості, зменшення робочих місць, розширення впливу транснаціональних корпорацій тощо. [3, с. 8-9; 4, с. 41-46]. Тому важливо, використовуючи економікоматематичні методи і моделі, всебічно дослідити переваги та ризики інтеграційних процесів для соціально-економічної сфери держави.

У загальному вигляді сутність постановки проблеми полягає у тому, щоб за допомогою використання методів економіко-математичного моделювання дослідити та 
пояснити вплив зовнішньо-торговельних чинників на соціально-економічні явища та процеси в Україні. Важливим науковим та практичним завданням $є$ також окреслення шляхів зменшення негативного впливу економічної інтеграції України на національне господарство. Розв'язання поставлених наукових та практичних завдань висвітлено у складових елементах даної наукової статті.

Аналіз останніх досліджень, у яких започатковано вирішення проблеми. Питаннями дослідження розвитку зовнішньої торгівлі України та ії впливу на соціальноекономічний стан держави, в тому числі із використанням методів економікоматематичного моделювання, займалися багато видатних науковців та практиків, зокрема: Булига К.Б. [16], Воропай Н.Л. [17], Голіков А.П. [18], Петрущак М.М. [14], Руденко Л.Г. [4], Сімахова А.О. [8] та інші.

Незважаючи на детальне висвітлення вченими питань впливу зовнішньоекономічних процесів на соціально-економічний стан країни, залишаються ще деякі питання, які вимагають додаткового дослідження. В умовах посилення інтеграційних прагнень України увага акцентується на чинниках, які своїм сумарним впливом формують стан національної економіки. Насамперед, це стосується чинників зовнішньоекономічної діяльності держави. Разом з тим, питання посилення позитивного впливу та зменшення негативних наслідків інтеграційних процесів для економіки держави на сучасному етапі посилення експортної активності країни залишаються ще недостатньо розкритими і потребують більш детального опрацювання.

Цілі статті полягають у дослідженні впливу зовнішньоекономічних факторів таких як експорт та імпорт товарів та послуг, зовнішньоекономічне сальдо та прямі іноземні інвестиції на рівень добробуту держави, основним із індикаторів якого $є$ значення ВВП України. Для досягнення цілей сформульовані завдання, основним із яких $\epsilon$ побудова та аналіз економіко-математичної моделі, яка б описувала залежність ВВП країни від зовнішньої торгівлі та прямих іноземних інвестицій. Виконання поставлених завдань дозволить визначити ступінь і напрям впливу зовнішньоекономічних факторів на рівень соціально-економічного розвитку країни. Результати аналізу сприятимуть обгрунтуванню напрямів розвитку зовнішньоекономічної діяльності України із врахуванням національних інтересів.

Виклад основного матеріалу дослідження 3 повним обгрунтуванням отриманих наукових результатів.

«Показник ВВП характеризує можливості економіки щодо забезпечення добробуту суспільства в трьох аспектах: ефективності розподілу виробництва на продукти проміжного та кінцевого призначення; структури кінцевого попиту (споживання, нагромадження, зовнішньоторговельне сальдо); первинних доходів» [5]. Окрім цього, ВВП $є$ ключовим показником для оцінки міжнародної конкурентоспроможності країни та базою для визначення системи індексів для оцінки місця країни у світовій системі.

Дослідимо зв'язок між чинниками зовнішньоекономічної діяльності та значенням ВВП України. Використовуючи можливості економіко-математичного моделювання, розглянемо багатофакторну модель залежності ВВП України на душу населення від основних чинників зовнішньоекономічної діяльності у такому вигляді:

$$
Y=a_{0}+a_{1} \cdot X_{1}+a_{2} \cdot X_{2}+\ldots+a_{m} \cdot X_{m}+l
$$
чинників.

де $Y$ - показник - значення ВВП на душу населення, яке залежить від системи

$X_{1}, X_{2}, \ldots X_{m}$ - незалежні чинники - система зовнішньоекономічних чинників;

m - кількість чинників.

1 - випадкова величина.

Для вибору системи зовнішньоекономічних чинників та загального вигляду економіко-математичної моделі використали результати наукових досліджень відомих економістів [6, 7,8]. 
Отож, показником та чинниками економіко-математичної моделі залежності ВВП від зовнішньоекономічної діяльності України були обрані:

$Y$ - ВВП на душу населення України;

$X_{1}$ - величина експорту товарів та послуг України;

$X_{2}$ - величина імпорту товарів та послуг України;

$X_{3}$ - величина зовнішньоторговельного сальдо;

$X_{4}$ - величина прямих іноземних інвестицій в економіку України.

Розглядаємо припущення про високу залежність ВВП на душу населення України від величини вартості експорту товарів та послуг $[6,7,8]$.

Вихідні дані для проведення моделювання були сформовані у таблицю 1 [9-13].

Таблиця 1

Вихідні дані для побудови моделі залежності ВВП на душу населення України від зовнішньоекономічних чинників за 2001-2020 роки

\begin{tabular}{|c|c|c|c|c|c|}
\hline Рік & $\begin{array}{c}\text { ВВП на душу } \\
\text { дол США }\end{array}$ & $\begin{array}{c}\text { Експорт товарів } \\
\text { та послуг, } \\
(X 1), \text { млрд. дол СШАА }\end{array}$ & $\begin{array}{c}\text { Імпорт } \\
\text { товарів та послуг, } \\
(X 2), \text { млрд. дол США }\end{array}$ & $\begin{array}{c}\text { Зовнішньо- } \\
\text { торговельне сальдо, } \\
(X 3), \text { млрд. дол США }\end{array}$ & $\begin{array}{c}\text { Прямі іноземні } \\
\text { інвестиції, }\end{array}$ \\
\hline 2001 & 784 & 19,81 & 16,92 & 2,89 & 0,6 \\
\hline 2002 & 883 & 22,01 & 18,17 & 3,84 & 0,7 \\
\hline 2003 & 1053 & 27,32 & 24,47 & 2,85 & 1,4 \\
\hline 2004 & 1372 & 37,98 & 31,06 & 6,92 & 7,8 \\
\hline 2005 & 1837 & 40,42 & 39,08 & 1,34 & 5,6 \\
\hline 2006 & 2312 & 45,87 & 48,75 & $-2,88$ & 10,0 \\
\hline 2007 & 3076 & 58,29 & 65,65 & $-7,36$ & 4,9 \\
\hline 2008 & 3904 & 78,74 & 92,00 & $-1,3,26$ & 6,5 \\
\hline 2009 & 2548 & 49,30 & 50,61 & $-3,00$ & 7,2 \\
\hline 2010 & 2979 & 63,19 & 66,19 & $-6,75$ & 8,4 \\
\hline 2011 & 3584 & 82,11 & 88,86 & $-9,02$ & 4,5 \\
\hline 2012 & 3866 & 82,34 & 91,36 & $-8,52$ & 0,4 \\
\hline 2013 & 4184 & 74,83 & 83,35 & 3,36 & 3,0 \\
\hline 2014 & 3061 & 64,11 & 60,75 & 3,82 & 3,3 \\
\hline 2015 & 2116 & 46,80 & 42,98 & 0,54 & 2,6 \\
\hline 2016 & 2186 & 45,11 & 44,57 & $-2,52$ & 2,4 \\
\hline 2017 & 2640 & 52,58 & 55,10 & $-6,21$ & 3,4 \\
\hline 2018 & 3095 & 57,28 & 63,49 & $-3,69$ & 2,2 \\
\hline 2019 & 3660 & 64,05 & 67,74 & $-0,22$ & \\
\hline 2020 & 3732 & 59,10 & 59,32 & & \\
\hline
\end{tabular}

Джерело: побудоване авторами на основі [9-13].

Для побудови економіко-математичної моделі використаємо можливості вбудованих електронних таблиць Excel Microsoft та дослідження вітчизняних вчених [14-18].

Перш ніж приступити до побудови економіко-математичної моделі перевіримо обрані чинники на мультиколінеарність. Мультиколінеарність - це негативне явище, яке зустрічається у моделях множинної регресії, передбачає тісну кореляційну залежність двох або більше чинників між собою та спотворює результати дослідження. Щоб перевірити наявність мультиколінеарності чинників використаємо методи кореляційного аналізу та представимо результати у таблиці 2.

Таблиця 2

Матриця парних коефіцієнтів кореляції зовнішньоекономічних чинників

\begin{tabular}{|c|c|c|c|c|c|}
\hline & $Y$ & $X 1$ & $X 2$ & $X 3$ & $X 4$ \\
\hline$Y$ & 1 & 0,968475 & 0,974135 & $-0,8379$ & 0,579237 \\
\hline$X 1$ & 0,968475 & 1 & 0,990258 & $-0,79767$ & 0,615372 \\
\hline$X 2$ & 0,974135 & 0,990258 & 1 & $-0,87387$ & 0,669177 \\
\hline$X 3$ & $-0,8379$ & $-0,79767$ & $-0,87387$ & 1 & $-0,74987$ \\
\hline$X 4$ & 0,579237 & 0,615372 & 0,669177 & $-0,74987$ & 1 \\
\hline
\end{tabular}

Джерело: побудоване авторами на основі результатів використання вбудованих функцій Excel Microsoft 
Результати кореляційного аналізу зовнішньоекономічних чинників моделі вказують, що на показник $Y$ обрані чинники мають наступний вплив: прямий і сильний вплив - чинники $X 1$ (вартість експорту товарів та послуг) та $X 2$ (вартість імпорту товарів та послуг); обернений і сильний - чинник $X 3$ (зовнішньоторговельне сальдо); прямий та середній - чинник $X 4$ (вартість прямих іноземних інвестицій). Також, спостерігаємо дуже тісний і прямий зв'язок між $X 1$ та $X 2$, для яких коефіцієнт парної кореляції становить 0,990258. Це свідчить про існування явища мультиколінеарності між двома чинниками $(X 1$ та $X 2)$ у багатофакторній моделі.

Щоб позбутися явища мультиколінеарності використаємо найлегший спосіб вилучення змінної, коли із системи вилучають той із колінеарних чинників, який має менший вплив на показник. Із колінеарних чинників $X 1$ та $X 2$ менший вплив на показник має $X 1$, оскільки значення його коефіцієнта кореляції з показником $\epsilon$ меншим $(0,968475$ $<0,974135)$. Тому чинник $X 1$ виключаємо із системи, а модель залежності ВВП на душу населення від зовнішньоекономічних чинників матиме вигляд:

$$
Y=a 0+a 2 X 2+a 3 X 3+a 4 X 4
$$

Сформуємо нову таблицю даних для проведення моделювання (таблиця 3).

Таблиця 3

Дані для побудови моделі залежності ВВП на душу населення України від зовнішньоекономічних чинників за 2001-2020 роки

\begin{tabular}{|c|c|c|c|c|}
\hline Рік & $\begin{array}{c}\text { ВВП на душу } \\
\text { населення }(Y), \\
\text { дол США }\end{array}$ & $\begin{array}{c}\text { Імпорт } \\
\text { товарів та послуг, } \\
(X 2), \text { млрд. дол США }\end{array}$ & $\begin{array}{c}\text { Зовнішньо-торговельне } \\
\text { сальдо, }\end{array}$ & $\begin{array}{c}\text { Прямі іноземні } \\
\text { інвестиції, } \\
(X 4), \text { млрд.дол США }\end{array}$ \\
\hline 2001 & 784 & 16,92 & 2,89 & 0,6 \\
\hline 2002 & 883 & 18,17 & 3,84 & 0,7 \\
\hline 2003 & 1053 & 24,47 & 2,85 & 1,4 \\
\hline 2004 & 1372 & 31,06 & 6,92 & 7,8 \\
\hline 2005 & 1837 & 39,08 & 1,34 & 5,6 \\
\hline 2006 & 2312 & 48,75 & $-2,88$ & 10,0 \\
\hline 2007 & 3076 & 65,65 & $-7,36$ & 10,9 \\
\hline 2008 & 3904 & 92,00 & $-13,26$ & 4,8 \\
\hline 2009 & 2548 & 50,61 & $-1,31$ & 6,5 \\
\hline 2010 & 2979 & 66,19 & $-3,00$ & 7,2 \\
\hline 2011 & 3584 & 88,86 & $-6,75$ & 8,4 \\
\hline 2012 & 3866 & 91,36 & $-9,02$ & 4,5 \\
\hline 2013 & 4184 & 83,35 & $-8,52$ & 0,4 \\
\hline 2014 & 3061 & 60,75 & 3,36 & 3,0 \\
\hline 2015 & 2116 & 42,98 & 3,82 & 3,3 \\
\hline 2016 & 2186 & 44,57 & 0,54 & 2,6 \\
\hline 2017 & 2640 & 55,10 & $-2,52$ & 2,4 \\
\hline 2018 & 3095 & 63,49 & $-6,21$ & 3,4 \\
\hline 2019 & 3660 & 67,74 & $-3,69$ & 2,2 \\
\hline 2020 & 3732 & 59,32 & $-0,22$ & \\
\hline
\end{tabular}

Для побудови економіко-математичної моделі використаємо стандартну функцію «Регресія» надбудови «Пакет аналізу» електронних таблиць Excel Microsoft i представимо результати у таблицях 4 і 5.

Таблиця 4

Основні показники достовірності економіко-математичної моделі

\begin{tabular}{|l|c|c|c|c|c|}
\hline & df & SS & MS & F & Значущість F \\
\hline Регресія & 3 & 19713634 & 6571211 & 70,85702 & $1,86 \mathrm{E}-09$ \\
\hline Залишок & 16 & 1483825 & 92739,04 & & \\
\hline Разом & 19 & 21197459 & & & \\
\hline
\end{tabular}


Таблиця 5

Значення коефіцієнтів економіко-математичної моделі

\begin{tabular}{|c|c|c|c|c|c|c|}
\hline & Коефіцієнти & $\begin{array}{c}\text { Стандартна } \\
\text { помилка }\end{array}$ & $\mathrm{t}$-розрахункове & Р-значення & Менше 95\% & Більше 95\% \\
\hline Показник & 158,2917381 & 323,9984 & 0,488557 & 0,631784 & $-528,554$ & 845,1377 \\
\hline$X 2$ & 49,68469002 & 6,113554 & 8,126974 & $4,52 \mathrm{E}-07$ & 36,72454 & 62,64484 \\
\hline$X 3$ & 1,285429984 & 30,24306 & 0,042503 & 0,966623 & $-62,827$ & 65,39785 \\
\hline$X 4$ & $-61,94902872$ & 33,27259 & $-1,86186$ & 0,081093 & $-132,484$ & 8,585707 \\
\hline
\end{tabular}

Також, отримали значення коефіцієнта множинної регресії $(0,9644)$, коефіцієнта детермінації $(0,93)$ та нормованого коефіцієнта детермінації $(0,9169)$.

Щоб перевірити значущості коефіцієнтів моделі використаємо критерій Стьюдента, сутність якого полягає у наступному: якщо для коефіцієнту регресії виконується умова $t p>t m a б л$, то він $є$ значимий. Табличне значення критерію Стьюдента при даних умовах (розглядаємо 20 часових періодів та ймовірність становить $0,95)$ становить $t т а б л=2,101$. Згідно критерію Стьюдента значимим $\epsilon$ лише чинник $X 2$ (імпорт товарів та послуг).

Отож, очікувана модель залежності ВВП на душу населення від зовнішньоекономічної діяльності країни зменшить свою ступінь та набере наступного вигляду:

$$
Y=a 0+a_{2} X_{2}
$$

До даних показника та обраного чинника $X_{2}$ застосуємо стандартну функцію «Регресія» надбудови «Пакет аналізу» електронних таблиць Excel Microsoft та представимо результати у таблицях 6-7. Крім того, значення коефіцієнта детермінації остаточної економіко-математичної моделі становить 0,9538, що свідчить про високу залежність показника ВВП на душу населення від чинника імпорту товарів та послуг.

Таблиця 6

Основні показники достовірності остаточної економіко-математичної моделі

\begin{tabular}{|l|c|c|c|c|c|}
\hline & df & SS & MS & F & Значущість F \\
\hline Регресія & 1 & 19282797 & 19282797 & 181,2803 & $7,74 \mathrm{E}-11$ \\
\hline Залишок & 18 & 1914661 & 106370,1 & & \\
\hline Разом & 19 & 21197459 & & & \\
\hline
\end{tabular}

Таблиця 7

Значення коефіцієнтів остаточної економіко-математичної моделі

\begin{tabular}{|c|c|c|c|c|c|c|}
\hline & Коефіцієнти & $\begin{array}{c}\text { Стандартна } \\
\text { помилка }\end{array}$ & t-розрахункове & Р-значення & Менше 95\% & Більше 95\% \\
\hline Показник & 210,0969 & 194,8995 & 1,077976 & 0,295279 & $-199,372$ & 619,5655 \\
\hline$X 2$ & 43,83032 & 3,255362 & 13,46404 & $7,74 \mathrm{E}-11$ & 36,99106 & 50,66958 \\
\hline
\end{tabular}

Знову використаємо критерій Стьюдента для перевірки суттєвості впливу чинника $X_{2}$ на показник $Y$. Табличне значення обраного критерію залишається незмінним (tmaбл=2,101). Оскільки розрахункове значення критерію Стьюдента для чинника $X_{2}$ більше за табличне $(13,464>2,101)$, то він є значимий і суттєво впливає на показник $Y$. Ще одним підтвердженням значимості чинника $X 2 \epsilon$ той факт, що його Р-значення $\epsilon$ менше за 0,05. Побудована економіко-математична модель залежності ВВП на душу населення від імпорту товарів та послуг є адекватна статистичним даним і може бути використана для аналізу. Такі висновки 3 ймовірністю 0,95 можемо зробити після використання критерію Фішера, оскільки його розрахункове значення є більшим за 
табличне $(181,28>4,41)$.

Отож, економіко-математична модель залежності ВВП України на душу населення від зовнішньоекономічної діяльності країни набуває наступного вигляду:

$$
\mathrm{Y}=210,0969+43,83032 * \mathrm{X} 2
$$

Порівняємо графіки статистичних даних ВВП України на душу населення та розрахункових даних ВВП України на душу населення, отриманих 3 економікоматематичної моделі (4) на Рис. 1.

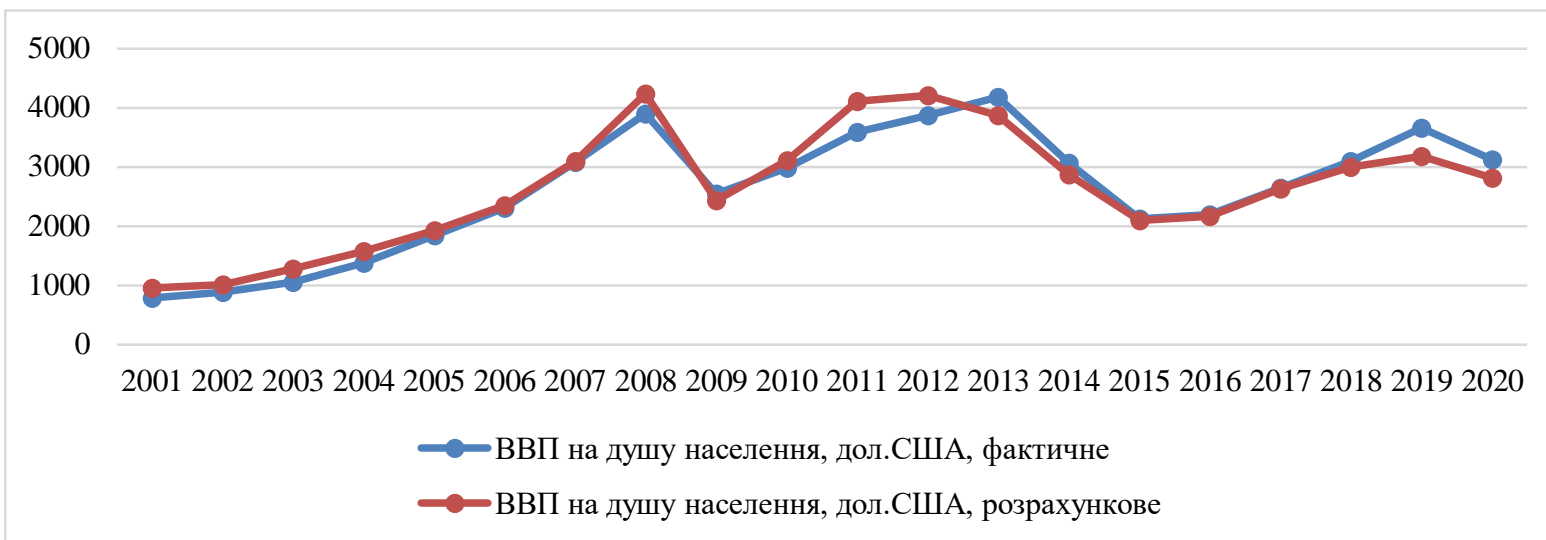

Рис. 1. Аналіз динаміки статистичних та розрахункових значень ВВП України на душу населення за 2001-2020 роки, дол США/душу населення

Проведений графічний аналіз динаміки статистичних та розрахункових значень ВВП України на душу населення за 2001-2020 роки підтверджує правильність побудови економіко-математичної моделі ВВП України на душу населення. Отож, результати економіко-математичного моделювання не підтверджують припущення про високу залежність ВВП України від експорту товарів та послуг, а підтверджують високу залежність від величини імпорту товарів та послуг.

Висновки. Отож, результати економіко-математичного моделювання вказують на те, що величина ВВП України, в кінцевому результаті залежить від імпорту товарів та послуг. Для пояснення результатів аналізу, проаналізуємо структуру імпорту України.

У 2020 році імпорт товарів та послуг України становив 59,32 млрд.дол США, причому 92,1\% займав імпорт товарів. У структурі імпорту товарів України найбільшу частку становить продукція машинобудування - 34,3\%, продукція хімічної промисловості - 19,9\% та 15,5\% - мінеральні продукти [19]. Подібна тенденція спостерігалася практично у всі роки досліджуваного періоду. Констатуємо, що національна економіка та й рівень розвитку соціально-економічної сфери країни загалом має високу ступінь залежності від імпорту машин та обладнання, продукції хімічної промисловості та мінеральних продуктів. Така загрозлива особливість національної економіки робить iї вразливою та залежною від мінливості кон'юнктури зовнішніх ринків.

Вирішення питання залежності вітчизняної промисловості, особливо машинобудівної та хімічної галузей, від імпортної сировини розглядається у Національній економічній стратегії на період до 2030 року. Серед основних стратегічних цілей розвитку промисловості виділяють: підвищення внутрішнього попиту на вітчизняну продукцію промисловості, створення умов для нарощення експорту продукції, впровадження ресурсо- та енергоефективних технологій для підвищення конкурентоспроможності вітчизняної продукції, активізація інноваційно-інвестиційної діяльності вітчизняних підприємств [20]. 


\section{Список бібліографічного опису:}

1. Про засади внутрішньої і зовнішньої політики: Закон України від 1 липня 2010 р. № 2411-VI. URL : http://zakon5.rada.gov.ua/laws/show/2411-17.

2. Тимошенко Л.М., Більська О.В. Соціальна компонента в забезпеченні цивілізаційного поступу і перспективні форми ії реалізації на національних теренах. Вісник Дніпропетровського університету. Серія: «Світове господарство і міжнародні економічні відносини». 2014. Вип. 6. С. 94-103.

3. Тохтамиш Т.О., Ягольницький О.А., Овчиннікова М.А. Теоретичні аспекти організації зовнішньої торгівлі України 3 країнами Свропейського Союзу. Проблеми системного підходу в економіці. 2018. Випуск № 2(64). С. 7-12. URL: http://psae-jrnl.nau.in.ua/journal/2_64_2018_ukr/1.pdf.

4. Руденко Л.Г., Лісовський С.А., Маруняк С.О. Виклики і загрози просторового розвитку України на шляху до євроінтеграції. Український географічний журнал. 2016. № 1. C. 41-46. URL: http://nbuv.gov.ua/UJRN/UGJ_2016_1_9.

5. Фатюха Н.Г., Макушина Т.П. Аналіз динаміки ВВП України. Електронний журнал «Ефективна економіка». 2015. № 12. URL : http://www.economy.nayka.com.ua/?op=1\&z=4634.

6. Власюк Т.О. Оптимізація імпортної політики як чинник зовнішньоекономічної безпеки. Проблеми економіки. 2015. № 3. C. 39-51.

7. Мазаракі А.А. Стратегія посткризового розвитку зовнішньоекономічного сектора України: монографія: за заг.ред. А.А. Мазаракі. К.: Київ. нац. торг.-екон. ун-т. 2014. 660 с.

8. Сімахова А.О. Аналіз впливу зовнішньоекономічних чинників на добробут населення України в умовах світових інтеграційних процесів. Маркетинг і менеджмент інноващій. 2016. № 3. С. 263-271.

9. Мінфін. Валовий внутрішній продукт (ВВП) в Україні 2021. URL: https://index.minfin.com.ua/ua/economy/gdp/.

10. Мінфін. Прямі іноземні інвестиції в Україну. URL: https://index.minfin.com.ua/ua/economy/fdi/2010/

11. Статистичний збірник «Україна у цифрах, 2020». Державна служба статистики України, 2021. 46 с.

12. Статистичний щорічник України за 2019 рік. Державна служба статистики України, за ред. І.С. Вернера. К.. 2020. 465 c. URL: http://www.ukrstat.gov.ua/druk/publicat/kat_u/2020/zb/11/zb_yearbook_2019.pdf.

13. Зовнішня торгівля України. Статистичний збірник. Державна служба статистики України. 2018. 86 c. URL: https://ukrstat.org/en/druk/publicat/kat_u/2018/zb/06/zb_ztu_2017.pdf.

14. Петращук М.М. Використання методів кореляційно-регресійного аналізу для моделювання рівня фінансового забезпечення інноваційної діяльності в Україні. Ефективна економіка. 2013. № 6. URL: http://www.economy.nayka.com.ua/?op=1\&z=2139.

15. Бережна Л.В., Снитюк О.І. Економіко-математичні методи та моделі у фінансах: навч. посіб. К.: Кондор. 2009.301c. 16. Булига К.Б., Міхайленко В.М. Комп'ютерний практикум із застосуванням математичних методів в економіці: навч. посіб. К.: Європ. ун-т фінансів, інформац. систем, менеджменту і бізнесу. 2000. 66 с.

17. Воропай Н.Л., Герасименко Т.В., Кирилова Л.О., Корсун Л.М., Мацкул М.В., Мальцева Є.В., Михайленко А.В., Орлов С.В., Чернишев В.Г., Чепурна О.С., Шинкаренко В.М. (за заг.редакцією Мацкул В.М.) Економіко-математичні методи та моделі: Навчальний посібник. Одеса: ОНЕУ. 2018. 404 с.

18. Голіков А.П. Економіко-математичне моделювання світогосподарських процесів: навч. посіб. Х.: ХНУ ім. В.Н. Каразіна. 2006. 144 с.

19. Офіційний сайт Міністерства економіки України. URL: https://www.me.gov.ua/Tags/DocumentsByTag?lang=ukUA\&id=ce61591c-858a-4e77-885e-edabb095097c\&tag=ZovnishniaTorgivlia-analitika-.

20. Національна економічна стратегія на період до 2030 року. URL: https://nes2030.org.ua/?fbclid=IwAR2n7HwFWa2nptw7alD_If6j8neTGLRaMJOXyV1OQcmCf34NHsjAXiw9YM\#rec246 061582.

\section{References:}

1. Pro zasady vnutrishnoi i zovnishnoi polityky: Zakon Ukrainy vid 1 lypnia 2010 r. № 2411-VI. URL : http://zakon5.rada.gov.ua/laws/show/2411-17. [in Ukrainian].

2. Tymoshenko L.M., Bilska O.V. Sotsialna komponenta v zabezpechenni tsyvilizatsiinoho postupu i perspektyvni formy yii realizatsii na natsionalnykh terenakh. Visnyk Dnipropetrovskoho universytetu. Seriia: «Svitove hospodarstvo i mizhnarodni ekonomichni vidnosyny». 2014. Vyp. 6. P. 94-103. [in Ukrainian].

3. Tokhtamysh T.O., Yaholnytskyi O.A., Ovchynnikova M.A. Teoretychni aspekty orhanizatsii zovnishnoi torhivli Ukrainy z krainamy Yevropeiskoho Soiuzu. Problemy systemnoho pidkhodu v ekonomitsi. 2018. Vypusk № 2(64). P. 7-12. URL: http://psae-jrnl.nau.in.ua/journal/2_64_2018_ukr/1.pdf. [in Ukrainian].

4. Rudenko L.H., Lisovskyi S.A., Maruniak Ye.O. Vyklyky i zahrozy prostorovoho rozvytku Ukrainy na shliakhu do yevrointehratsii. Ukrainskyi heohrafichnyi zhurnal. 2016. № 1. P. 41-46. URL: http://nbuv.gov.ua/UJRN/UGJ_2016_1_9. [in Ukrainian].

5. Fatiukha N.H., Makushyna T.P. Analiz dynamiky VVP Ukrainy. Elektronnyi zhurnal «Efektyvna ekonomika». 2015. № 12. URL : http://www.economy.nayka.com.ua/?op=1\&z=4634. [in Ukrainian].

6. Vlasiuk T.O. Optymizatsiia importnoi polityky yak chynnyk zovnishnoekonomichnoi bezpeky. Problemy ekonomiky. 2015. № 3. P. 39-51. [in Ukrainian].

7. Mazaraki A.A. Stratehiia postkryzovoho rozvytku zovnishnoekonomichnoho sektora Ukrainy: monohrafiia: za zah.red. A.A. Mazaraki. K.: Kyiv. nats. torh.-ekon. un-t. 2014. 660 p. [in Ukrainian].

8. Simakhova A.O. Analiz vplyvu zovnishnoekonomichnykh chynnykiv na dobrobut naselennia Ukrainy v umovakh svitovykh intehratsiinykh protsesiv. Marketynh i menedzhment innovatsii. 2016. № 3. P. 263-271. [in Ukrainian].

9. Minfin. Valovyi vnutrishnii produkt (VVP) v Ukraini 2021. URL: https://index.minfin.com.ua/ua/economy/gdp/. [in Ukrainian]

10. Minfin. Priami inozemni investytsii v Ukrainu. URL: https://index.minfin.com.ua/ua/economy/fdi/2010/. [in Ukrainian].

11. Statystychnyi zbirnyk «Ukraina u tsyfrakh, 2020». Derzhavna sluzhba statystyky Ukrainy, 2021. 46 p. [in Ukrainian]. 
12. Statystychnyi shchorichnyk Ukrainy za 2019 rik. Derzhavna sluzhba statystyky Ukrainy, za red. I.Ie. Vernera. K.. 2020. 465 s. URL: http://www.ukrstat.gov.ua/druk/publicat/kat_u/2020/zb/11/zb_yearbook_2019.pdf. [in Ukrainian].

13. Zovnishnia torhivlia Ukrainy. Statystychnyi zbirnyk. Derzhavna sluzhba statystyky Ukrainy. 2018. 86 s. URL: https://ukrstat.org/en/druk/publicat/kat_u/2018/zb/06/zb_ztu_2017.pdf. [in Ukrainian].

14. Petrashchuk M.M. Vykorystannia metodiv koreliatsiino-rehresiinoho analizu dlia modeliuvannia rivnia finansovoho zabezpechennia innovatsiinoi diialnosti v Ukraini. Efektyvna ekonomika. 2013. № 6. URL: http://www.economy.nayka.com.ua/?op=1\&z=2139. [in Ukrainian].

15. Berezhna L.V., Snytiuk O.I. Ekonomiko-matematychni metody ta modeli u finansakh: navch. posib. K. : Kondor. 2009. 301 p. [in Ukrainian].

16. Bulyha K.B., Mikhailenko V.M. Kompiuternyi praktykum iz zastosuvanniam matematychnykh metodiv v ekonomitsi: navch. posib. K.: Yevrop. un-t finansiv, informats. system, menedzhmentu i biznesu. 2000. 66 p. [in Ukrainian].

17. Voropai N.L., Herasymenko T.V., Kyrylova L.O., Korsun L.M., Matskul M.V., Maltseva Ye.V., Mykhailenko A.V., Orlov Ye.V., Chernyshev V.H., Chepurna O.Ie., Shynkarenko V.M. (za zah.redaktsiieiu Matskul V.M.) Ekonomiko-matematychni metody ta modeli: Navchalnyi posibnyk. Odesa: ONEU. 2018. 404 p. [in Ukrainian].

18. Holikov A.P. Ekonomiko-matematychne modeliuvannia svitohospodarskykh protsesiv: navch. posib. Kh.: KhNU im. V.N. Karazina. 2006. 144 p. [in Ukrainian].

19. Ofitsiinyi sait Ministerstva ekonomiky Ukrainy. URL: https://www.me.gov.ua/Tags/DocumentsByTag?lang=ukUA\&id=ce61591c-858a-4e77-885e-edabb095097c\&tag=ZovnishniaTorgivlia-analitika-. [in Ukrainian].

20. Natsionalna ekonomichna stratehiia na period do 2030 roku. URL: https://nes2030.org.ua/?fbclid=IwAR2n7HwFWa2nptw7alD_If6j8neTGLRaMJOXyV1OQcmCf34NHsjAXiw9YM\#rec246 061582. [in Ukrainian].

Дата подання публікації 08.10.2021 р.

UDC 339.727.22

Галазюк Н.М., к.е.н., доцент

Galaziuk N. Candidate of Economic Sciences, Associate Professor https://orcid.org/0000-0001-7918-4268

Зелінська О.М., к.е.н., доцент

Zelinska O. Candidate of Economic Sciences, Associate Professor

https://orcid.org/0000-0001-9103-6460

\section{CURRENT TRENDS OF TRANSNATIONAL BANKS AND THEIR INFLUENCE ON THE WORLD ECONOMY IN THE CONTEXT OF FINANCIAL GLOBALIZATION}

\section{Lutsk national technical university}

Financial globalization is the development of global financial markets, the growth of cross-border capital flows and increased activity of international financial organizations. At the same time, speaking of financial globalization means the free movement of capital between countries.

A key feature of international banking is the strengthening of transnationalization in the context of financial globalization. As a result of this process, at the present stage of the development of the world economy, there is no net national banking capital in any state of the world.

Transnational banks are one of the main actors in the world economy. They occupy a leading position in the international financial market and are the participants in the globalization process in the financial sphere. Thus, the international financial system has become for transnational banks the so-called arena of activity of «financial giants» as transnational banks.

The combined capital of multinational banks is easily transferred from one state to another with the most controversial consequences. On the one hand, consolidated capital becomes a driving force for the development of STP (scientific and technological progress) on the world stage, and on the other hand for severe global crises transforming into speculative capital. The importance of transnational banks both in the economic environment of an individual state and in the world economy as a whole is growing rapidly.

One of the important roles that transnational banks play is the role of an intermediary between financial means owners and investors who, in order to implement international business activities, borrow capital from TNB. Usually, the arrival of transnational banks on the foreign market becomes a certain stimulus factor for the restructuring of the banking system of the host country. This is manifested in an increase in the concentration of bank capital or the creation of a strong competitive environment among local banking institutions. Moreover, very often host countries make a big mistake in implementing too liberal risk policies to maximize income, in which 